\title{
CONTROL OF STEMBORER [Nupserha sp. near vexator (Pascoe)], A NEW PEST OF SUNFLOWER (Helianthus annuus L.), BY CONVENTIONAL INSECTICIDES
}

\author{
Patil, B.V. , Bilapate, G.G. and Jadhav, R.N.
}

Oilseeds Research Station, Latur - 413512 Maharashtra State, India

Received: July 09, 2007

Accepted: May 15, 2009

\section{SUMMARY}

Sunflower (Helianthus annuus L.) is an important oilseed crop. Several pest are known to attack sunflower crop. Sunflower cultivation in Marathwada region (M.S., India) has recently been threatened by a new pest, the stem borer Nupserha sp. near vexator (Pascoe). The stem borer appeared on sunflowers at Latur (M.S.) for the first time in India in 1993. Severe incidence of the stem borer was recorded in Marathwada region since 1998 which led to poor grain filling and ultimately yield loss to the extent of $30 \%$. This situation led prompted us to test several conventional insecticides with the objective of finding a chemical that effectively controls the stem borer. A field study was carried out at Oilseeds Research Station, Latur (M.S.), during Kharif 2004-06. Six conventional insecticides were tested along with the untreated control. Application of quinalphos was found to be most effective and economic in controlling the stem borer, followed by chlorpyriphos and endosulfan.

Key words: sunflower, stem borer, incidence, control, treatment

\section{INTRODUCTION}

Sunflower (Helianthus annuus L.) is the fourth most important oilseed crop in the world, after soybean, groundnut and rapeseed. During 2004-05 in India, sunflowers occupied an area of 2.162 million ha, with a production of 1.224 million tons and an average yield of $566 \mathrm{~kg} / \mathrm{ha}$ (Anonymous ${ }^{2}$, 2006). Sunflower has gradually replaced many crops due to its economic advantages. Recently, the sunflower cultivation in Marathwada region (Maharashtra State, India), has been threatened by a new pest, identified as the stem borer. The stem borer appeared on sunflowers at Latur (Marathwada) for the first time in India in 1993 and was identified in 1999. Its scientific name is Nupserha sp. near vexator (Pascoe). It is a coleopterous grub

* Corresponding author: Phone/Fax: (off.)+91-02382-245294; Resi:+91-02382-224939; M:+91-09421363306; e-mail: patilbvors@rediffmail.com 
that belongs to the family Cerambycidae, Lamiinae. A severe incidence of the stem borer was recorded (30-70\%) in farmers' fields during a survey of kharif sunflower in Latur District (Anonymous, 1998). The stem borer incidence in farmers' fields in July-sown crop was $42-55 \%$ while $20-25 \%$ incidence was recorded in August-sown sunflowers during a pest survey in Marathwada region (Anonymous, 2001). Maximum incidence (25\%) was recorded at Ambulga village, Latur District (Anonymous, 2004). Stem borer incidence ranging from 10-25\% was observed in most locations in Latur District (Anonymous ${ }^{1}, 2006$ ). The grub is wide at the anterior end and it tapers towards the posterior end. The whitish creamy eggs are laid singly in leaf axils. The newly hatched grub enters the stem 3-3.5" above the collar region. The entrance hole can be seen at the bottom of the stem. The grub bores upwards through the internal pith tissue and pupates. Later on, the grub escapes into the soil making an exit hole at stem bottom or remains in the stem through the resting stage. Affected stems break easily if pressed. Infested plants lodge during the grain formation stage, which leads to poor grain filling and ultimately results in the yield loss up to $17.5 \%$ (Anonymous, 2005), although a loss of $31.0 \%$ was also reported (Anonymous ${ }^{1}$, 2006). This situation moved us to conduct this experiment on chemical control of the stem borer.

Table 1: Evaluation of certain insecticides against stem borer in sunflower (three-year pooled data, 2004-2006)

\begin{tabular}{|c|c|c|c|c|c|c|c|}
\hline \multirow{2}{*}{ No. } & \multirow{2}{*}{ Treatment } & \multicolumn{3}{|c|}{$\%$ of stem borer incidence } & \multirow{2}{*}{ Total } & \multirow{2}{*}{$\begin{array}{l}\text { Pooled } \\
\text { mean }\end{array}$} & \multirow{2}{*}{$\begin{array}{c}\% \text { SB incidence } \\
\text { reduction }\end{array}$} \\
\hline & & $2004-05$ & $2005-06$ & $2006-07$ & & & \\
\hline 1 & $\begin{array}{l}\text { Endosulfan } \\
@ 0.07 \%\end{array}$ & $\begin{array}{c}11.7 \\
(20.02)\end{array}$ & $\begin{array}{c}11.3 \\
(19.64)\end{array}$ & $\begin{array}{c}5.1 \\
(13.00)\end{array}$ & $\begin{array}{c}28.1 \\
(52.66)\end{array}$ & $\begin{array}{c}9.4 \\
(17.55)\end{array}$ & 71.5 \\
\hline 2 & $\begin{array}{l}\text { Monocrotophos } \\
@ 0.05 \%\end{array}$ & $\begin{array}{c}13.5 \\
(21.54)\end{array}$ & $\begin{array}{c}23.0 \\
(28.52)\end{array}$ & $\begin{array}{c}14.7 \\
(22.55)\end{array}$ & $\begin{array}{c}51.2 \\
(72.61)\end{array}$ & $\begin{array}{c}17.1 \\
(24.20)\end{array}$ & 48.0 \\
\hline 3 & $\begin{array}{l}\text { Acephate } \\
@ 0.075 \%\end{array}$ & $\begin{array}{c}21.0 \\
(27.26)\end{array}$ & $\begin{array}{c}38.3 \\
(38.25)\end{array}$ & $\begin{array}{c}17.8 \\
(24.89)\end{array}$ & $\begin{array}{c}77.1 \\
(90.40)\end{array}$ & $\begin{array}{c}25.7 \\
(30.13)\end{array}$ & 22.0 \\
\hline 4 & $\begin{array}{l}\text { Dichlorvos } \\
@ 0.075 \%\end{array}$ & $\begin{array}{c}21.5 \\
(27.74)\end{array}$ & $\begin{array}{c}36.0 \\
(36.83)\end{array}$ & $\begin{array}{c}17.9 \\
(25.03)\end{array}$ & $\begin{array}{c}75.4 \\
(89.60)\end{array}$ & $\begin{array}{c}25.1 \\
(29.87)\end{array}$ & 24.0 \\
\hline 5 & $\begin{array}{l}\text { Quinalphos } \\
@ 0.05 \%\end{array}$ & $\begin{array}{c}8.4 \\
(16.74)\end{array}$ & $\begin{array}{c}7.3 \\
(15.66)\end{array}$ & $\begin{array}{c}3.9 \\
(11.28)\end{array}$ & $\begin{array}{c}19.6 \\
(43.68)\end{array}$ & $\begin{array}{c}6.5 \\
(14.56)\end{array}$ & 80.3 \\
\hline 6 & $\begin{array}{l}\text { Chlorpyriphos } \\
@ 0.05 \%\end{array}$ & $\begin{array}{c}9.7 \\
(17.88)\end{array}$ & $\begin{array}{c}8.7 \\
(17.05)\end{array}$ & $\begin{array}{c}9.0 \\
(17.45)\end{array}$ & $\begin{array}{c}27.4 \\
(52.38)\end{array}$ & $\begin{array}{c}9.1 \\
(17.46)\end{array}$ & 72.4 \\
\hline \multirow[t]{3}{*}{7} & Untreated-Control & $\begin{array}{c}22.9 \\
(28.60)\end{array}$ & $\begin{array}{c}47.3 \\
(43.47)\end{array}$ & $\begin{array}{c}28.8 \\
(32.44)\end{array}$ & $\begin{array}{c}99.0 \\
(104.51)\end{array}$ & $\begin{array}{c}33.0 \\
(34.84)\end{array}$ & - \\
\hline & SEm \pm & & & & & 2.09 & \\
\hline & $C D(P=0.05)$ & & & & & 6.45 & \\
\hline
\end{tabular}

Numbers in parenthesis are angular transformed values

\section{MATERIAL AND METHODS}

The field experiment was conducted during kharif (July-August sowing) 200406 at Oilseeds Research Station, Latur, (M.S.) India. Six conventional insecticides were tested (Table 1) along with the untreated control in a randomized block design with three replications and the experimental unit size of $5.0 \times 4.5 \mathrm{~m}$. The sunflower 
cultivar used in the experiment was Morden. All recommended agronomic practices were followed. Control of stem borer is difficult because the insect spends most of its life inside plant stems, where it is protected from standard chemical control (Sloderbeck et al., 1996). Therefore only the exposed stages of the pest, i.e., eggs, newly hatched larvae and adults, were targeted by spraying at 25 and 40 days after emergence with a foot sprayer. Observations were made at the time of harvest by cutting the stem at collar region. The incidence of stem borer was calculated on the basis of damaged plant percentage in experimental plots. The net plot $(3.0 \times 3.9 \mathrm{~m})$ yield of the crop was recorded separately. The data generated during three years were subjected to statistical analysis and cost benefit ratio was also worked out for each treatment.

\section{RESULTS AND DISCUSSION}

Three-year pooled results presented in Table 1 show that the stem borer incidence varied significantly within the treatments. The application of quinalphos $0.05 \%$ was found to be significantly superior in reducing the stem borer incidence to the extent of $80.3 \%$. Similarly effective were also chlorpyriphos $0.05 \%$, which provided $72.4 \%$ reduction, and endosulfan $0.07 \%$, for which $71.5 \%$ reduction in stem borer incidence was recorded. The treatment with monocrotophos $0.05 \%$ also proved to be effective, with $48 \%$ reduction in pest incidence. Although the application of acephate $0.075 \%$ and dichlorvos $0.075 \%$ had significantly reduced the pest incidence in relation to the control, they proved to be less effective than the previous chemicals, as they recorded lowest reductions in the incidence of stem borer, 22 and $24 \%$, respectively. The highest pest incidence recorded in the untreated control was $33 \%$. The incidence of stem borer ( $N$. vexator) in sunflower was significantly reduced in the chemical module comprising diamethoate, quinalphos and endosulfan (Anonymous, 2001). The treatment with quinalphos $0.05 \%$ was found to be most effective and economic for the control of the stem borer in sunflower (Anonymous $\left.{ }^{1}, 2006\right)$. The lambda cyhalothrin and permethrin were found to be more toxic than carbaryl for soybean stem borer, as reported by Michell et al. (2000). Quinalphos $0.03 \%$ proved to be highly toxic to eggs and grubs of the girdle beetle in soybean, causing 93.3\% mortality in grubs (Singh, 1986). Efficacy of quinalphos against the girdle beetle in soybean was reported by Keshbhat et al. (2004) who also recorded the highest yield in this treatment. Thus the present findings are in conformity with the earlier studies. Table 2 shows that significant variation within treatment was also evident in seed yield response. The highest seed yield $(889 \mathrm{~kg} / \mathrm{ha})$ was registered with the application of quinalphos $0.05 \%$, which was $24 \%$ higher and significant in relation to the control. This treatment was on par with chlorpyriphos $0.075 \%(847 \mathrm{~kg} / \mathrm{ha})$ and endosulfan $0.07 \%(839 \mathrm{~kg} / \mathrm{ha})$ which recorded yield increases of 18 and $17 \%$, respectively, both of which were significant in relation to the control. The rest of the treatments stood on par with the untreated 
control. It was also shown in Table 3 that the highest cost benefit ratio (ICBR) was registered with the application of quinalphos $0.05 \%$ (1:2.3) followed by chlorpyriphos $0.05 \%(1: 2.2)$ and endosulfan $0.07 \%$ 1:2.2. The lowest ICBR was recorded in the untreated control, $1: 1.8$.

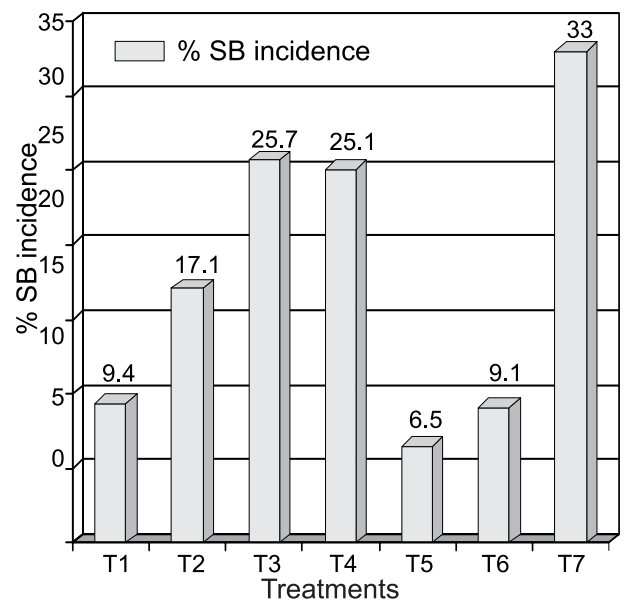

Figure 1: Performance of various treatments against stem borer

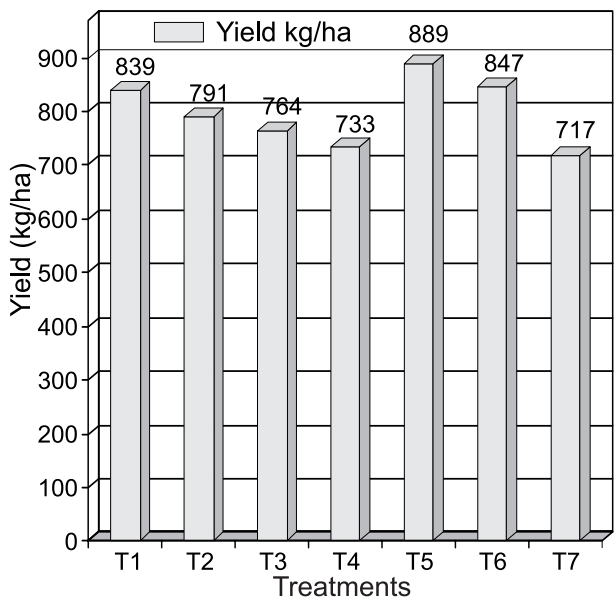

Figure 2: Yield response to various treatments

Table 2: Yield response to various treatments (three-year pooled data, 2004-2006)

\begin{tabular}{llccccc}
\hline \multirow{2}{*}{ No. } & Treatment & \multicolumn{3}{c}{ Yield, kg/plot } & Weighed & $\begin{array}{c}\text { Yield } \\
\text { mean }\end{array}$ \\
\cline { 2 - 4 } kg/ha
\end{tabular}

Hectare factor $=854.70$

\section{CONCLUSION}

Of the insecticides tested, the application of quinalphos $0.05 \% 25$ and 40 days after emergence proved to be effective and economical for the control of the stem borer Nupserha sp. near vexator (Pascoe) in sunflower, followed by chlorpyriphos $0.05 \%$ and endosulfan $0.07 \%$. 


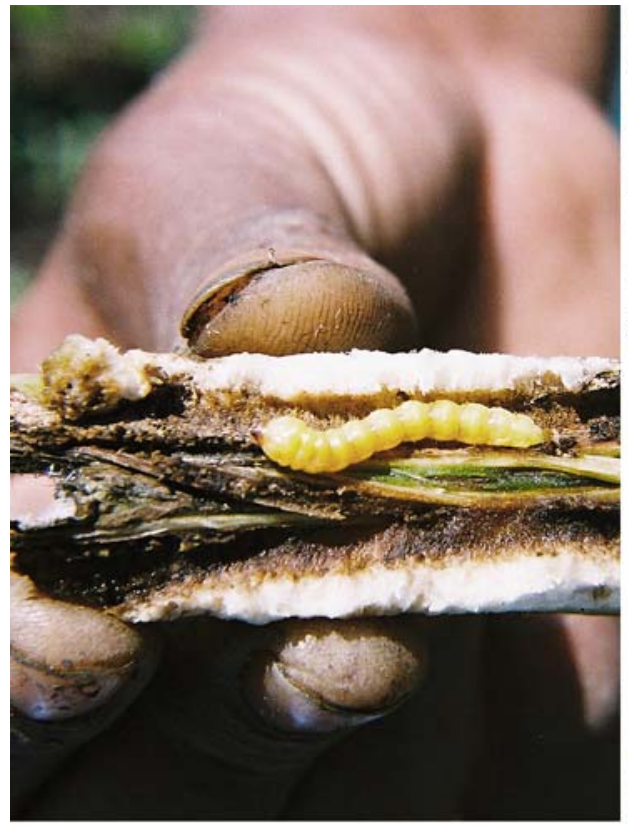

Figure 3: Grubs of the stem borer, Nupserha sp near vexator (Pascoe), in sunflower

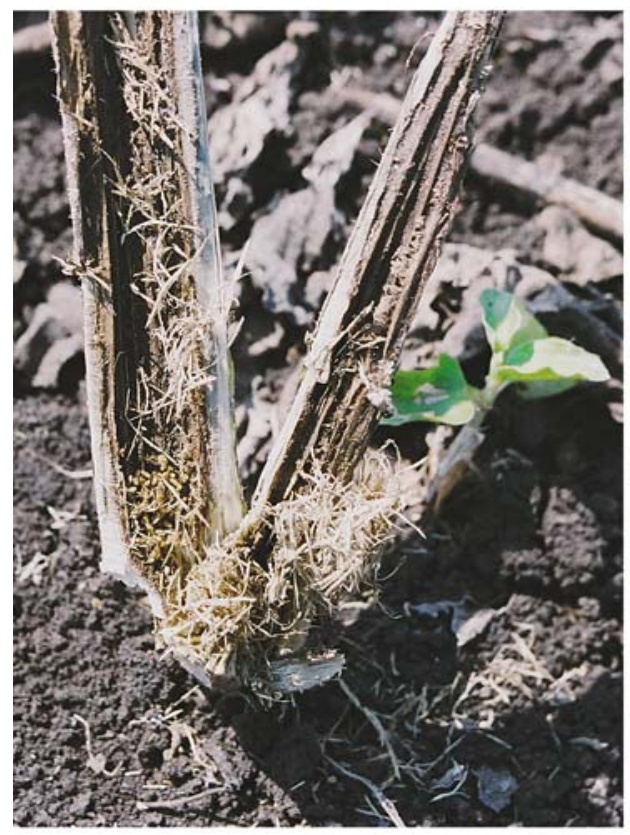

Figure 5: Severe sunflower stem damage by stem borer

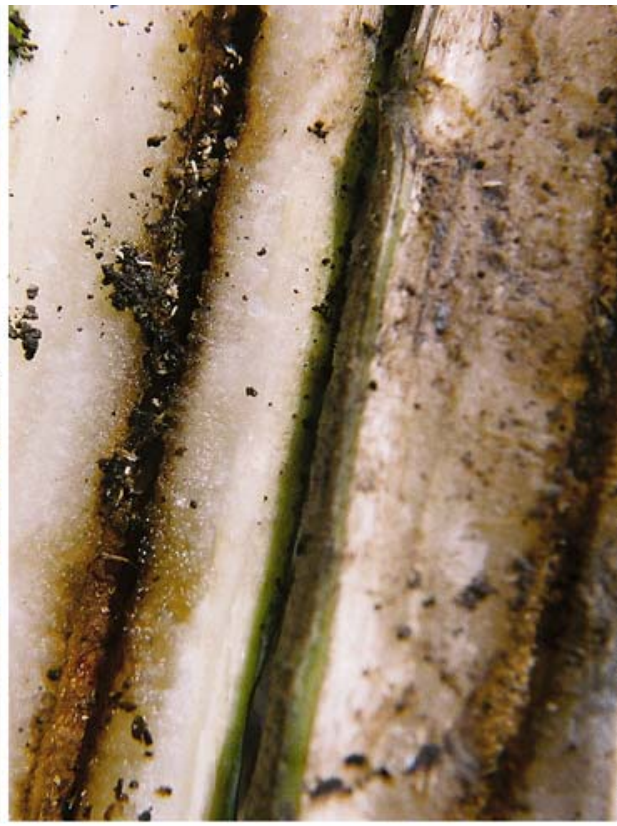

Figure 4: Grub feeds on internal pith tissue making a tunnel

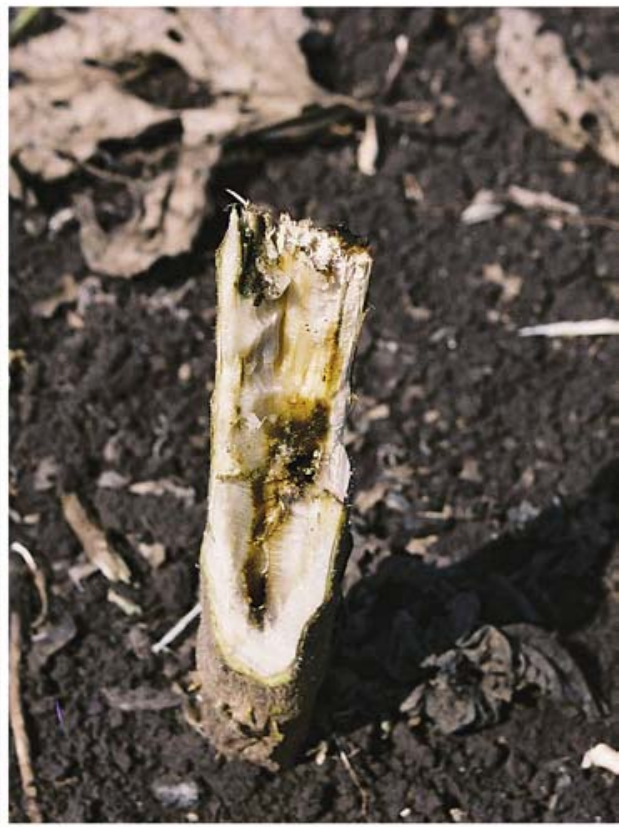

Figure 6: Finally, the grub makes an exit hole at the bottom and escapes into the soil for pupation 


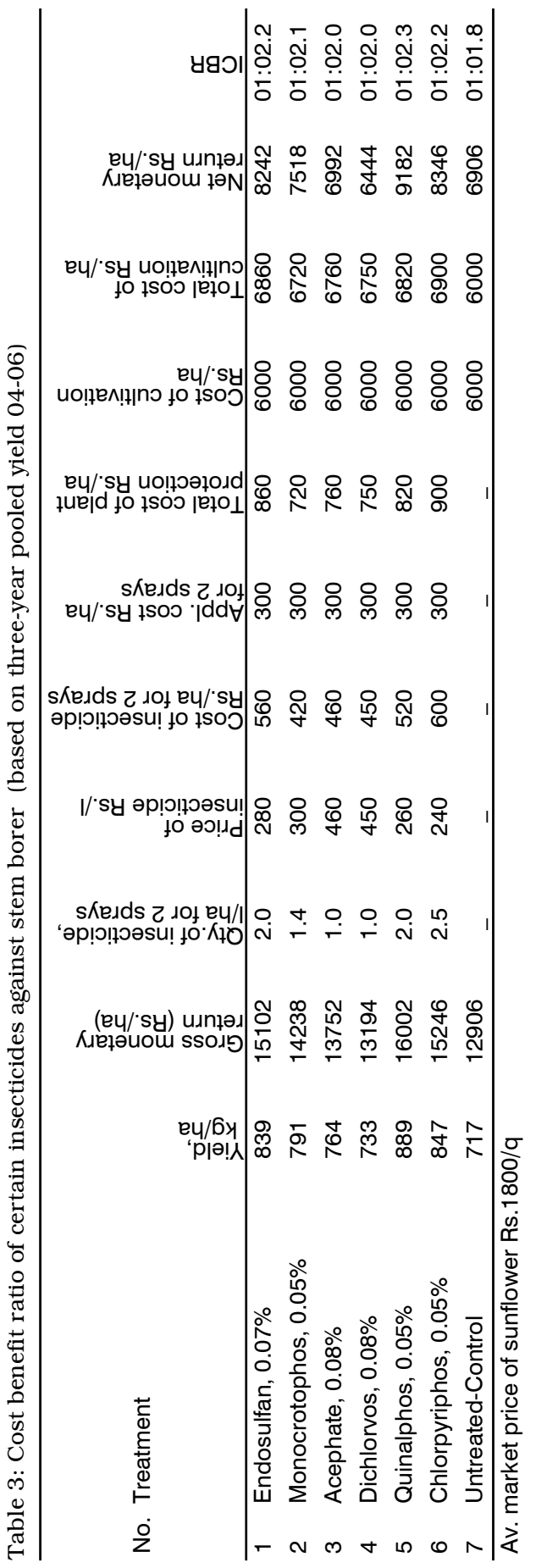




\title{
ACKNOWLEDGEMENTS
}

The authors are grateful to Director of Research, MAU, Parbhani, and Project Director, DOR, Hyderabad, for providing funds and facilities that enabled us to conduct this study.

\section{REFERENCES}

Anonymous, 1998. Annual progress report. All India Coordinated Research Project on Sunflower, DOR, Hyderabad, India, pp. 168.

Anonymous, 2001. Annual progress report. All India Coordinated Research Project on Sunflower, DOR, Hyderabad, India, pp. 141-158.

Anonymous, 2004. Annual progress report. All India Coordinated Research Project on Sunflower, DOR, Hyderabad, India, pp. 156.

Anonymous, 2005. Annual progress report. All India Coordinated Research Project on Sunflower, DOR, Hyderabad, India, pp. 172.

Anonymous $^{1}$, 2006. Annual progress report. All India Coordinated Research Project on Sunflower, DOR, Hyderabad, India, pp. 146-163.

Anonymous $^{2}$, 2006. Strategies for enhancing sunflower production in India. Directorate of Oilseeds Research (ICAR), Rajendra Nagar, Hyderabad, India, pp. 1.

Keshbhat, S.S., Bidgire, U.S., Suryawanshi, D.S., 2004. Field efficacy of different insecticides against stemfly, Melangromyza sojae $\mathrm{Z}$. and girdle beetle, Oberiopsis brevis $\mathrm{S}$. on soybean, Glycine max Merill. J. Oilseeds Research 21(1): 202-203.

Kaczmarek, M., Yanzhu, K., Hingins, R. and Sloderbeck, P.E., 2000. Comparative toxicities of three insecticides to the soybean stem borer, Dectes texanus texanus (Coleoptera, Cerambycidae) adults. North Central Branch of the Entomological Society of America.

Sloderbeck, P.E., Brooks, H.L. and Bell Jr., K.O., 1996. Soybean stem borer. Entomology 156 (L.D.), KSU, Manhattan.

Singh, O.P., 1986. Toxicity of insecticides on the eggs and grubs of girdle beetle, Oberea brevis Swed, a pest of soybean in M.P. Legume Research 9(1): 11-15.

\section{CONTROL DEL BARRENADOR DEL TALLO [(Nupserha sp. near vexator (Pascoe)], UNA NUEVA PESTE DEL GIRASOL (Helianthus annuus L.), A TRAVÉS DE INSECTICIDAS CONVENCIONALES}

\author{
RESUMEN
}

El girasol (Helianthus annuus L.) es un importante cultivo oleaginoso a nivel mundial. Se sabe que el cultivo de girasol es afectado por muchas pestes. Recientemente el cultivo de girasol en la región de Marathwada (M.S.), India se enfrentó a la amenaza de una nueva peste, el barrenador del tallo Nupserha sp. near vexator (Pascoe). El barrenador del tallo apareció por primera vez en India en 1993 en Latur (M.S.). A partir de 1998 se registraron severas incidencias del barrenador en la región de Marathwada lo que afectó el llenado de granos y generó pérdidas de hasta el 30\% del rendimiento. Esta situación condujo a evaluar la eficacia de algunos insecticidas convencionales contra el barrenador del tallo. El estudio a campo se condujo en la Oilseeds Research Station, Latur, M.S., durante la estación Kharif de los años 2004-2006. Se evaluaron seis insecticidas convencionales además del control no tratado. Se encontró que el tratamiento más efectivo y económico fue el de aplicación de Quinalphos, seguido por Chlorpyriphos y Endosulfan. 
TRAITEMENT DE L'INSECTE Nupserha sp. near vexator (Pascoe), NOUVEL INSECTE NUISIBLE AU TOURNESOL (Helianthus annuus L.) aU MOYEN D'INSECTICIDES CONVENTIONNELS

\author{
RÉSUMÉ
}

Le tournesol (Helianthus annuus L.) est la plante oléagineuse importante dans le monde. Il est connu pour être infesté par différents insectes nuisibles. Récemment la culture du tournesol dans la région de Marathwada (M.S., Inde) a été infectée par un nouvel insecte nuisible proche de Nupserha vexator (Pascoe). La foreuse de tige est apparue à (M.S.), pour la première fois en Inde, en 1993. Une incidence sévère de la foreuse de tige a été rapportée dans la région de Marathwada depuis 1998, ce qui a conduit à un faible remplissage des grains et finalement à une perte de rendement allant jusqu'à $30 \%$. Cette situation a conduit à tester l'efficacité d'insecticides conventionnels pour évaluer l'efficacité de produits chimiques contre la foreuse de tige. L'expérimentation au champ a été menée à la Station de Recherche sur les Oléagineux de Latur (M.S.) au cours de la saison Kharif de 2004 à 06. Six insecticides conventionnels ont été testés en comparaison avec un témoin non traité. Pour le contrôle de la foreuse de tige, l'application de quinalphos a été trouvée à la fois la plus efficace et la plus économique, suivie par le chlorpyriphos et l'endosulfan. 